Volume 4 No. 1, Juni 2019

P ISSN 2442-594X | E ISSN 2579-5708

http://journal.iainlangsa.ac.id/index.php/tibyan

DOI: $10.32505 /$ tibyan.v4i1.847

\title{
MAKNA MAHAR DALAM ALQURAN \\ (Kajian Historis-Antropologis)
}

The Meaning Of Expenses In The Qur'an (Historical-Anthropological's Studies)

\author{
Mochammad Tholib Khoiril Waro \\ Mahasiswa Program Pasca Sarjana UIN Sunan Kalijaga Yogyakarta \\ 16tholib@gmial.com
}

\begin{abstract}
This study discusses the meaning of dowry contextually by using a historicalanthropological approach, assuming the dowry verse does not descend in empty space, but descends in the midst of the seventh-century ignorance Arab society which already has deep-rooted traditions. Anthropologically, the meaning of the dowry tradition is inseparable from the dynamics of culture that existed at that time. The scope of this study includes four things, first, the tradition of mahr in the ignorance period, second, the dialectic of God's revelation with the dowry tradition and the third review of Tasyakkul-Tasykil Nasr Hamid Abu Zayd's theory and the fourth, anthropological studies of religion as culture with Geertz's theory model of reality and model for reality. In this study, there is a dialectic between the revelation of God and the tradition of dowry in the ignorant Arab community who consider dowry as a medium of exchange for women to be married. Alquran is present, by adopting the tradition of dowry that has been running but constructs the meaning and practice of dowry based on the world view Alquran. Alquran means dowry as a mandatory gift for proof of love and sincerity (saduqat) which is given voluntarily (nihlah) with the intention of worshiping Allah.
\end{abstract}

Keywords: Mahar, Historical-Anthropological, Dialectic revelation of God, World view Alquran

\begin{abstract}
Abstrak
Penelitian ini membahas makna mahar secara kontekstual dengan menggunakan pendekatan historis-antropologis, dengan asumsi ayat mahar tidak turun diruang kosong, melainkan turun ditengah-tengah masyarakat arab jahiliyah abad ke-VII yang sudah memiliki tradisi mengakar.Secara antropologis, pemaknaan terhadap tradisi mahar tidak terlepas dari dinamika
\end{abstract}


kebudayaan yang ada pada saat itu. Ruang lingkup kajian penelitian ini mencakup empat hal, yaitu pertama, tradisi mahar pada masa jahiliyah, kedua, dialektika wahyu Tuhan dengan tradisi mahar dan ketigatelaah teori Tasyakkul-Tasykīl Nasr Hamid Abu Zayd dan keempat telaah antropologis agama sebagai budaya dengan teori model of reality dan model for reality milik Geertz. Dalam penelitian ini menunjukkan adanya dialektika antara wahyu Tuhan dengan tradisi mahar pada masyarakat arab jahiliyah yang menganggap mahar sebagai bentuk alat tukar atas perempuan yang akan dinikahi. Alquran hadir, dengan mengadopsi tradisi mahar yang sudah berjalan namun mengkonstruksi makna dan praktek mahar berdasarkan world view Alquran. Alquran memaknai mahar sebagai pemberian wajib atas bukti cinta dan kesungguhan (șaduqāt) yang diberikan secara sukarela (niḥlah) dengan niat beribadah kepada Allah.

Kata Kunci: Mahar, Historis-Antropologis, Dialektika wahyu Tuhan, World view Alquran

\section{Pendahuluan}

Pada abad modern saat ini Islam telah menjadi kajian yang menarik minat banyak kalangan baik di Barat maupun Timur yang kemudian melahirkan Studi Islam (Islamic Studies). Islam tidak lagi hanya dipahami dalam pengertian normatif dan doktriner tetapi telah berkembangn menjadi fenomena yang kompleks, baik dari sistem budaya, peradaban, komunitas politik, dan ekonomi. Mengkaji dan mendekati Islam, tidak lagi mungkin hanya dari satu aspek, karenanya dibutuhkan metode dan pendekatan interdisipliner dari ilmu-ilmu sosial lainnya. Islamic studies sebagaimana tersebut diatas dikaji dengan menggunakan interdisipliner ilmu-ilmu sosial dan humanities, yang menghasilkan berbagai macam fokus keahlian dalam pengkajian Studi Islam.

Namun, dalam beberapa literatur terutama fikih klasik masih banyak ditemui kajian-kajian bercorak normatif, dan parsial. Misal kajian terhadap makna mahar yang masih berputar pada pengertian lama. Imam Syafi'i mengatakan bahwa mahar adalah sesuatu yang wajib diberikan oleh seseorang lelaki kepada perempuan untuk dapat menguasai seluruh anggota badannya. ${ }^{1}$ Sedangkan ulama Maliki mendefinisikan mahar sebagai mā yaj'alu li al-zaujati fi nazîiri al-istimtā'i fiha yang berati mahar adalah sesuatu yang dijadikan (dibayarkan) kepada istri sebagi imbalan atas jasa pelayanan seksualitasnya. $^{2}$

Berdasarkan pemaparan makna mahar di atas, secara singkat dapat dilihat mahar sering diartikan secara normatif sehingga membuat pemaknaan mahar menjadi lebih sempit dan uncontextual. Hal-hal tersebut membuat penulis tertarik untuk mengkaji

\footnotetext{
${ }^{1}$ Slamet Abidin, Fiqih Munakahat 1, (Bandung: CV Pustaka Setia,1999), 106.

${ }^{2}$ Darmawan,Eksistensi Mahar \& Walimah, (t.t: Srikandi, 2007), 5.
} 
pemaknaan mahar secara historis-antropologis ${ }^{3}$ mengingat ayat-ayat tentang mahar tidak turun pada satu ruang kosong, melainkan turun ditengah-tengah bangsa arab yang sudah memiliki berbagai macam sistem kebudayaan yang mengakar. Penelitian ini dilakukan guna menjelaskan makna mahar dengan menggunakan pendekatan historisantropologis. Adapun teori yang dipakai adalah teori Tasyakkul dan Tasykīl dari Nasr Hamid Abu Zayd dan teori antropologi agama yang menyebutkan agama sebagai budaya (model of reality dan model for reality) dari Geertz.

\section{Arab Pra-Islam (Jāhiliyah)}

Istilah Jahiliyyah, yang biasanya diartikan sebagai masa kebodohan atau kehidupan barbar, sebenarnya berarti bahwa ketika itu orang-orang arab tidak memiliki otoritas hukum, nabi dan kitab suci. Pengertian ini dipilih karena mengingat masyarakat Arab Selatan yang berkebudayaan dan mampu baca tulis dengan baik disebut sebagai masyarakat bodoh dan barbar. ${ }^{4}$

Bangsa Arab termasuk dalam ras Semit. Bahasa dan bangsa Semit adalah istilah yang diberikan para sejarawan terhadap bangsa-bangsa yang berbahasa Arab, Ibrani, Ethiopia, Phoenisia, Assyiria, dan Aramea. Bangsa Arab merupakan bangsa yang paling mampu memelihara karakteristik ras Semit. Bahasa Arab pun merupakan bahasa rumpun Semit yang paling terpelihara. Suku-suku di jazirah Arabia, berdasarkan tempat ditinggalnya dikelompokkan menjadi dua, yaitu Arab Selatan dan Arab Utara. Dua kelompok ini memiliki karakter yang berbeda. Orang-orang Arab Selatan kebanyakan termasuk masyarakat perkotaan yang tinggal di Yaman, Hadramaut, dan di sepanjang pesisirnya. Dalam bidang peradaban, mereka lebih unggul daripada orang Arab Utara.

Dari sisi Genealogis, orang Arab Selatan termasuk keluarga Bangsa Arab asli ('Aribah) yang berasal dari keturunan Qahthan. Termasuk dalam golongan ini adalah orang-orang Madinah yang mendukung Nabi. Mereka adalah ketururnan dari suku-suku di Yaman. Orang Ghassan di Suriah Timur dan orang Lakhmi di Hiraq (Iraq) adalah orang Arab selatan yang berdomisili di Utara. kebalikan dari Arab Selatan, orang Arab Utara merupakan masyarakat nomad yang tinggal di rumah-rumah bulu di Hijaz dan Nejed. Mereka menggunakan bahasa Arab yang paling unggul. Pradaban mereka tidak pernah muncul hingga datangnya Islam. Orang-orang Arab Utara merupakan keturunan Adnan dan telah mengalami naturalisasi di tanah Arab. Mereka bikan bagsa Arab asli, tetapi bangsa Arab yang telah terarabkan (must'aribah). Suku Quraisy termasuk kedalam kelompok ini. ${ }^{5}$

\footnotetext{
${ }^{3}$ Pendekatan antropologis dalam memahami agama dapat diartikan sebagai salah satu upaya memahami agama dengan cara melihat wujud praktek keagamaan yang tumbuh dan berkembang dalam masyarakat. Melalui pendekatan ini agama nampak akrab dan dekat dengan masalah-masalah yang dihadapi manusia dan berupaya menjelaskan dan memberikan jawabannya. Dengan kata lain bahwa caracara yang digunakan dalam disiplin ilmu antropologi dalam melihat suatu masalah digunakan pula untuk memahami agama.

${ }^{4}$ Philip K Hitti, History Of The Arabs, Jakarta: Serambi Ilmu Semesta, 2008, hlm. 108

${ }^{5}$ Philip K Hitti, History Of The Arabs, Jakarta: Serambi Ilmu Semesta, 2008, hlm. 37-40
} 
Secara umum, penduduk Arab terbagi menjadi dua kelompok, yaitu 'Arab atau penduduk kota dan $A^{\prime}$ rab atau penduduk desa. Penduduk 'Arab bertempat tinggal di kota yang merupakan pusat peradaban. Mereka memiliki rumah yang berbentuk permanen. Sebutan mereka adalah Ahl al-Madar atau penduduk kota. Mereka hidup dengan berdagang sehingga lebih maju kehidupannya. Akan tetapi, semangat individualism mereka sangat kuat daripada komunalisme. Hal ini disebabkan perdagangan telah menimbulkan transformasi pemikiran dikalangan mereka.

Kelompok A'rab hidup dalam tenda-tenda dan disebut dengan Ahl al-Wabar (penduduk desa) atau dikenal dengan suku Badui. Setiap tenda mewakili sebuah keluarga, yang merupakan satu rumah tangga yang terdiri dari ayah, anak laki-lakinya, dan keluarga mereka yang merupakan keturunan langsung. ${ }^{6}$ Wilayah yang ditempati tenda-tenda berbentuk hayy. Semua anggota hayy membentuk sebuah klan (qawm), dimana hak dan tanggung jawab klan bersifat kolektif berdasarkan solidaritas kelompok atau ashabiyah. ${ }^{7}$ Sejumlah klan yang sedarah kemudian bersama-sama membentuk suku (qabilah). ${ }^{8}$

Așabiyyah memiliki peran penting dalam perjalanan dakwah Nabi, danAșabiyyah yang dimaksud disini adalah individu-individu dalam unit-unit sosial yang menjadi bagian dari struktur sosial masarakat Arab Pra dan era kenabian Muhammad. Masyarakat Arab terdiri dari kabilah-kabilah, suku-suku, lapisan sosial, kelompokkelompok dan keluarga, mereka bekerja sama dan saling menolong untuk meraih kemaslahatan bersama. Diantara aṣabiyyah yang melekat pada sosial kemasyarakatan Arab pra kenabian Muhammad, adalah pertamaașabiyyah yang didasarkan pada hubungan kekerabatan dan keluarga. Kedua, așabiyyah yang didasarkan pada kabilah. Ketiga, așabiyyah yang didasarkan pada persekutuan antar kabilah atau așabiyyah partai (faksi). Keempat, așabiyyah yang didasarkan pada perwalian atau kesetiaan. Kelima, așabiyyah yang didasarkan pada perlindungan. Keenam, așabiyyah yang didasarkan pada partai (taqlid). ${ }^{9}$

Masyarakat Badui tinggal di padang pasir yang hidup tanpa air dan tumbuhtumbuhan. Mereka tidak suka bertani, tetapi lebih suka berperang dan membunuh. Sumber perekonomian mereka adalah pedang dan panah. Masyarakat ini mewakili bentuk adaptasi kehidupan manusia terhadap kondisi lingkungannya. Pekerjaan utama

\footnotetext{
${ }^{6}$ Levy, Susunan Masyarakat Islam, hlm. 1

${ }^{7}$ Ira M Lapidus, Sejarah SosilUmat Islam, trj. Gufron A Mas'adi..., hlm.19 Ashabiyah adalah solidaritas sosial yang dibentuk oleh ikatan satu keturunan. Dalam masyarakat Badui, ashabiyah (fanatisme kesukuan) memiliki peran yang sangat fital. Semangat ashabiyah akan menjadikan mereka sebagai kelompok yang kuat dan disegani, karena akan menimbulkan rasa saling membantu, gotongroyong, dan memperbesar rasa takut dalam diri musuh. Inilah makna penting dari ungkapan Nabi, "pelajarilah silsilah keluargamu untuk mengetahui siapa saudaramu sedarah yang dekat,"yang berarti bahwa persaudaraan akan berfungsi apabila pertalian darah itu membawa kerjasama yang sebenarnya dan bantu membantu dalam bahaya. Lihat dalam Ibnu Khaldun, Muqadimah Ibnu Khaldun, terj. Ahmadie Thaha, Jakarta: Pustaka Firdaus, 2006, hlm. 151-152.

${ }^{8}$ Philip K Hitti, History Of The Arabs..., hlm. 32.

${ }^{9}$ Aksin Wijaya, Sejarah Kenabian, Dalam Perspektif Tafsir Nuzuli Muhammad Izzat Darwazah, (Bandung: Mizan, 2016), hlm. 175-186.
} 
adalah peggembala ternak (pastoral). ${ }^{10}$ Mereka adalah kelompok suku nomad ${ }^{11}$ yang berkelana dari satu wilayah ke wilayah lain. Tujuannya adalah mencari daerah-daerah yang berumput dan memiliki sumber air untuk kehidupan mereka dan ternaknya. Meskipun nomad, mereka memiliki tatanan nilai, kebiasaan, dan adat istiadat sendiri. Identitas mereka dapat dilihat dari cara berpakaian. Mereka biasanya memakai pakaian bawah yang panjang (tasub) dan ikat pinggang. Pakaian atasnya longgar (aba) dan menggunakan penutup kepala berupa syal (kufiyya) yang diikat dengan tali ( 'iqad).

Salah satu pola paling khas dari organisasi sosial suku badui adalah solidaritas yang berbasis pada hubungan darah dan ikatan simbolik (dasar-dasar kesetaraan, otonomi dan pengakuan pada reputasi). Organisasi tersabur terkait erat dengan kerasnya kehidupan gurun yang menuntuk adanya militanasi dan adanya konstansi dalam mencari rumput dan air. ${ }^{12}$

Organisasi kesukuan dibangun berdasarkan Sistem demokrasi. Stuktur kekuasaan tertinggi dipegang oleh kepala suku yang disebut dengan syaikh. Kepala suku dipilih berdasarkan keturunan atau sifat kebangsawanannya. Kadang juga karena kekayaan, kebijaksanaan, atau pengalamannya. ${ }^{13}$ Tugas kepala suku adalah menyelesaikan masalah-masalah internal sesuai tradisi kelompok. Namun, dia tidak berhak mengatur, memerinah, atau menjatuhkan hukuman. ${ }^{14}$ Dalam masalah hukum, militer, dan kepentingan bersama, seorang syaikh tidak memiliki otoritas yang absolut. Dia harus berkonsultasi dengan dewan suku yang terdiri atas kepala keluarga.

Dalam tatanan hukum sosial Arab dikenal yang namanya solidaritas artifisial atau biasa disebut half atau tahalluf. Solidaritas ini berbentuk perserikatan antar suku yang berada dalam satu wilayah tertentu. Mereka bersekutu dan mengikatkan diri dengan sumpah atau perjanjian suci. Alasan terbentuknya itu adalah untuk menghadapi adanya persaingan dan pertentangan antar suku di Arab. ${ }^{15}$ Kabilah suku-suku Quraisy pernah melakukan perjanjian half dengan kabilah-kabilah lain. Mereka berkumpul dirumah Abdullah Ibn Jud'an Ibn 'Amr Ibn Ka'b Ibn Sa'd Ibn Taimi Ibn Murrah Ibn Ka'b Ibn Luay. Suku-suku yang menggabungkan diri dalam perjanjian ini adalah: Bani hasyim, Bani Muthallib, Asab Ibn Abdul 'Uzza, Zahrah Ibn Kilab, dan Taim Ibn Murrah. Perjanjian ini dikenal dengan Half al-Fudhu. ${ }^{1}$ Disebut fuḍl karena oranghlm. 67

${ }^{10}$ Halim Barakat, Dunia Arab, Masyarakat, Budaya dan Negara, (Bandung: Nusa Media, 2012),

${ }^{11}$ Suku badui yang paling nomad adalah mereka yang bermata pencaharian sebagai penggembala unta dan hidup jauh dipelosok gurun, tipe suku badui lain adalah mereka yang suka menggembala ternak dan domba, namun tipe ini tidak sering berpindah dan hidup tidak terlalu dipelosok. Lihat dalam Halim Barakat, Dunia Arab, Masyarakat, Budaya dan Negara, (Bandung: Nusa Media, 2012), hlm. 67

${ }^{12}$ Halim Barakat, Dunia Arab, Masyarakat, Budaya dan Negara, (Bandung: Nusa Media, 2012), hlm. 67-68

${ }^{13}$ Asghar Ali Engineer, Asal Usul Perkembangan Islam, hlm. 23

${ }^{14}$ Ira M. Lapidus, Sejarah Sosial Ummat Islam, Bagian Kesatu dan Kedua, trj. Gufron A. Mas'adi (Jakarta: Rajawali Press, 1999), hlm. 19

15 Djaka Soetapa, Ummah: Komunitas Religius, Sosial dan Politis dalam Alquran, (Yogyakarta: Duta Wacana University Press, 1991), hlm. 66.

${ }^{16}$ Ibnu Hisyam, Sirah Nabawiyyah, Juz I (Kairo: Dār al-Fikr, t.th), hlm. 148 
orang yang ada didalamnya adalah orang-orang yang bijak dan ahli di bidangnya. Kalau ada masalah diantara masyarakat, masalah tersebut diserahkan kepada ahlinya. Para ahli bermusyawarah lalu memutuskan suatu perkara. Sumpah setia half al-fuḍul mengandung sisi positif karena ia digunakan untuk menyelesaikan konflik di antara kabilah, atau membela kelompok yang terdzalimi, sehingga Hassan Hanafi menyebutnya sebagai model Islam sebelum kehadiran agama Islam. ${ }^{17}$

Struktur kekerabatan masyarakat Arab adalah patriarchal. ${ }^{18}$ Sistem patrialkal ini lebih dominan berlaku di Makkah. Garis laki-laki, dalam Sistem ini, menjadi penentu nasab seseorang. Otoritas tertinggi berada dibawah laki-laki yang tertua atau kepala keluarga. Pernikahan bersifat virilocal, tetapi juga berlaku uxorilocal. Pada masa menjelang kelahiran Islam, Sistem ini menggantikan Sistem matrialkal.

Kedudukan seorang perempuan tidak selalu sama dalam sebuah suku. Ada suku yang menempatkan perempuan dalam posisi inferior, tetapi ada juga yang menempatkan perempuan sejajar dengan laki-laki. Perempuan suku badui menikmati kebebasan yang lebih luas dari pada perempuan di perkotaan. ${ }^{19}$ Meskipun terjadi praktik poligami, mereka bebas memilih calon suami dan bebas pula menceraikannya. ${ }^{20}$ Di satu sisi, perempuan dianggap bukan keluarga penuh, karena kondisi biologis mereka tidak sesuai dengan karakter suku yang gemar berperang. Tetapi, terdapat pula kebebasan perempuan dalam perdagangan, pernikahan, maupun dalam hal lain. Sistem poliandri menunjukkan kebebasan wanita dalam memilih suami. Hal ini menunjukkan adanya pengaruh yang besar dari kaum perempuan terhadap laki-laki.

Di Makkah, yang merupakan kota perdagangan, tidak terdapat stuktur pemerintahan yang mengendalikan masyarakat. Otoritas masyarakat dipegang oleh dewan klan (mala), semacam dewan klan atau senat yang anggotanya terdiri dari wakil-wakil suku. Lembaga ini lebih menyerupai lembaga musyawarah dan tidak memiliki hak eksklusif (kemerdekaan bertindak). Otoritasnya hanya seputar masalah moralitas tanpa disertai kewenangan bertindak. Disamping itu, terdapat institusi lokal yang memiliki fungsi tertentu. ${ }^{21}$

${ }^{17}$ Hassan Hanafi, 'Ulūm al-Sirah: Min al-Rasūl ila al-Risālah, (Kairo: Madbuli, 2013), hlm. 171172.

${ }^{18}$ Dalam sebuah keluarga arab tradisional sosok sang ayah memegang otoritas dan tanggung jawab penuh. Sementara sang istri bergabung dengan kelompok kerabat suaminya (pola kekerabatan patrilokal) sedangkan anak-anak memakai nama ayah sebagai nama keluarga (keturunan patrilineal. Ayah mengiginkan keputusan dan kehormatan atas segala keputusannya, dan posisinya dipuncak piramida otoritas didasarkan atas pembagian tenaga kerja tradisional, yang mengesahkan perannya sebagai pemberi nafkah atau pencari nafkah. Lihat dalam Halim Barakat, Dunia Arab, Masyarakat, Budaya dan Negara, (Bandung: Nusa Media, 2012), hlm. 133.

${ }^{19}$ Dulu untuk menyatakan penolakan kepada seorang suami, para wanita diperkenankan membalik arah pintu tendanya sebagai kode bahwa ia tidak menginginkan hubungan pernikahannya dilanjutkan. Namun karena Alquran tidak menentang tradisi ini secara jelas, maka hak perceraian juga berlaku bagi perempuan sekarang. Lihat dalam Amina Wadud, Quran And Women, Reading The Sacred Text From A Woman's Perspektive, (Oxford: Oxford Unniversity Press, 1999), hlm. 80

${ }^{20}$ Philip K Hitti, History Of The Arabs..., hlm. 325

${ }^{21}$ Ira M. Lapidus, Sejarah Sosial Ummat Islam, Bagian Kesatu dan Kedua, trj. Gufron A. Mas'adi,... hlm. 27. Diantaranya: jabatan nasi, yang memiliki wewenang menentukan bulan sesuai dengan kalender 
Makah merupakan satu diantara beberapa tempat di Arabia yang memiliki sesuatu yang mengambang, hal tersebut dikarenakan Makah menjadi pusat peradaban yang menjadikan berkumpulnya semua warga dari lapisan manapun, sehingga memunculkan keanekaragaman budaya. Konsep kesukuan menjadi memudar dan terjadi proses individualisasi. Kesetiaan suku diperlukan sebatas untuk mengganti ketiadaan otoritas hukum yang mengatur kehidupan. Kelas-kelas sosial juga terbentuk di Makkah. Masyarakat dapat dikelompokkan kedalam kategori sosial berdasarkan statusnya dalam masyarakat. Ada warga yang mengambang dalam arti bernaung dibawah suku manapun, ada warga individual yang terusir dari kesukuan sejumlah pengungsi, budak, dan pedangang asing. ${ }^{22}$

Berbeda dengan di Makkah yang memilki lembaga mala, masyarakat Madinah malah tidak memilki lembaga pemerintahan. Masing-masing suku mempunyai at uran sendiri yang dipegang untuk anggotangya. Hal ini kerap kali menimbulkan permusuhan antar suku, karena ketiadaan lembaga mediator. Masyarakat madinah merupakan masyarakat yang heterogen. Terdapat sebelas klan dan delapan diantaranya beragama Yahudi. Penduduknya terdiri dari tiga komunitas besar, yaitu kelompok yahudi, Arab pagan, dan penganut Kristen. Di antara tiga komunitas tersebut, kelompok Yahudi yang paling mendominasi. Merekalah yang memiliki lahan pertanian dan perkebunan serta menguasai perdagangan. di samping itu, mereka juga memiliki profesi sebagai tukang emas dan pandai besi. ${ }^{23}$

\section{Tradisi Mahar Bangsa Arab}

Sistem kekerabatan yang berlaku di arab adalah patriarchal agnatic, dimana sekelompok masyarakat menurun berdasarkan garis laki-laki dan berada dibawah kekuasaan laki-laki yang paling tua. ${ }^{24}$ Laki-laki adalah kepala keluarga, sedangkan kedudukan wanita adalah inferior yakni berada dibawah bayang-bayang laki-laki bahkan tidak memiliki hak penuh sebagai warga. Keadaan tersebut memunculkan sistem sosial yang memandang rendah status wanita. Pandangan lemah terhadap

bulan (lunar system); Siqāyah, yang mengurusi suplai air bagi para peziarah, termasuk didalamnya pembagian air zamzam; Rifādah, yang bertugas mengurusi para peziarah; dan Liwa' yang bertugas menyiapkan dan mengurus sarana perang. Lihat dalam Ali Sodiqin, Antropologi Alquran,..hlm.4. lihat juga dalam Zulkifli, Mozaik Sejarah Islam,(Yogyakarta: Nusantara Press, 2011), hlm 28. Menurut Quraish Shihab setidaknya terdaat lima belas jabatan yang diemban oleh para pengelola makkah, adapun yang terpentig dianataranya adalah apa yang sudah disebutkan sebelumnya, sedangkan sisanya adalah, Al-Shadanah, yang bertugas untuk membawa kunci Ka'bah; al-Imarah, bertugas menjaga kehormatan Ka'bah; Dar al-Nadwah, tempat pertemuan para tokoh masyarakat untuk menyelesaikan sebuah permasalahan penting; al-Isynaq, bertugas menangani diyat; al-Asyar, bertugas menangani pengundian nasib dan alat-alatnya; al-Hukumah, bertugas melerai perselisihan dan menetapkan putusan, al-Safarah, bertugas menangani urusan luar suku (menteri luar negeri) lihat dalam Quraish Shihab, Membaca Sirah Nabi Muhammad Dalam Sorotan Alquran Dan Hadits-Hadits Shahih,... hlm. 58-59

${ }^{22}$ Ira M. Lapidus, Sejarah Sosial Ummat Islam, Bagian Kesatu dan Kedua, trj. Gufron A. Mas'adi,... hlm. 27

${ }^{23}$ Ali Sodiqin, Antropologi Alquran,..hlm.46-47

${ }^{24}$ Ira M Lapidus, Sejarah SosilUmat Islam, trj. Gufron A Mas'adi (Jakarta: Raja GrafindoPersada, 1999) hlm.42. 
wanita berdampak panjang terhadap hukum yang berlaku di masyarakat, dan kebanyakan hukum yang berlaku mengalami bias gender.

Mahar menjadi bagian dari tradisi bangsa arab dan menjadi trend sosial yang berlaku. Kedudukan mahar tidak lebih sebagai alat tukar bagi perempuan yang akan dikawinkan. ${ }^{25}$ Hal ini disebabkan karena pernikahan dipandang sama dengan transaksi jual-beli. Pembayaran mahar diberikan kepada orang tua calon mempelai dan besarnya ditentukan oleh kedudukan sosial suku perempuan tersebut. Dengan membayar mahar, berarti perempuan tersebut dibeli laki-laki calon suaminya. Perempuan dalam hal ini diperlakukan sebagai objek dari transaksi yang tidak memiliki hak apapun terhadap dirinya. Pada kenyataanya mahar sering kali disalah gunakan, karena mahar banyak diberikan kepada wali wanita sehingga membuat mereka dapat menyimpan dan tidak memberikannya pada mempelai perempuan.

Diantara praktek mahar pada zaman jahiliyah adalah adanya tradisi nikah mahar, yaitu sebuah praktek dimana seorang laki-laki datang menemui laki-laki lain dengan membawa saudara perempaunya dan memberikan saudara perempuannya kepada lakilaki tersebut, kemudian laki-laki tersebut juga memberikan saudara perempuanya kepada laki-laki yang pertama, dan terjadilah pertukaran wanita sebagai mahar atas wanita yang lain, begitulah mahar diparkatekan pada masa jahiliyah hanya sebatas alat tukar $^{26}$

\section{Proses Dialektika Alquran dengan Tradisi Mahar Bangsa Arab}

Proses dialektika Alquran dengan tradisi mahar arab jahiliyyah sudah terjalin sejak awal Alquran itu diturunkan, lebih khususnya pada periode makkah akhir. Alquran menyinggung kisah pernikahan Musa dengan salah satu anak Syuaib yang didalamya terdapat ibrah dalam praktek mahar yang sesuai dengan world view Alquran. Namun demikian ayat tersebut hanya berfungsi sebagai inżar at au peringatan keras bahwa dalam praktek mahar masyarakat arab jahiliyah banyak terjadi penyimpangan yang tidak sejalan dengan dengan world view Alquran.

\section{Periode Makkah}

Ayat makiyyah yang berbicara masalah pernikahan adalah Surat al-Qașaṣ [28]: $27-28$.

${ }^{25}$ Pemaknaan mahar yang seperti ini muncul berdasarkan pandangan peniliti barat terhadap praktik mahar di masyarakat arab, sedangkan pemaknaan lain atas mahar adalah sebuah salah satu cara untuk melindungi perempuan, terutama ketika bercerai, dan sebagai uang yang dapat digunakan untuk membeli pakaian atau perhiasan. Sementara yang lain berpandangan bahwa mahar hanyalah hadiah simbolik semata. Lihat dalam Halim Barakat, Dunia Arab, Masyarakat, Budaya dan Negara..., hlm. 147

${ }^{26}$ Abu Ja'far al-Tabari. Jāmi' al-Bayān fì Ta’wìl al-Qurān Juz 7,..., hlm.553. 


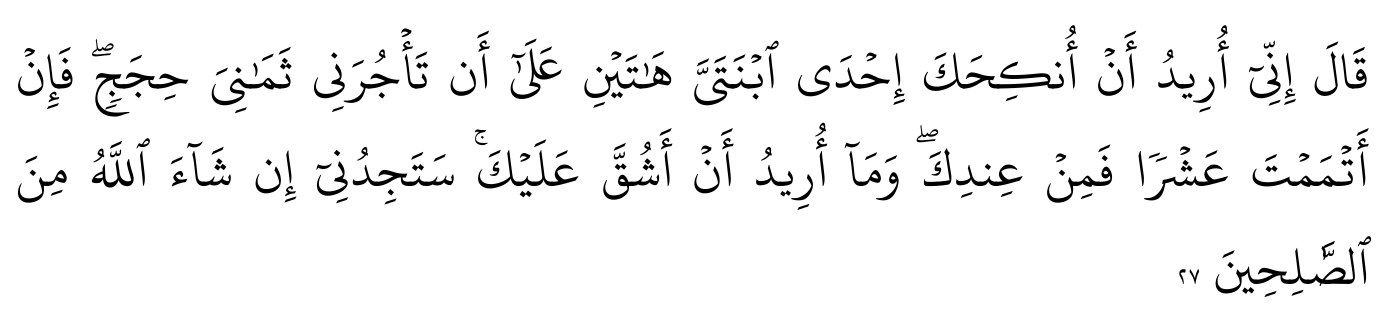

Terjemah: 27. Berkatalah dia (Syu'aib): "Sesungguhnya aku bermaksud menikahkan kamu dengan salah seorang dari kedua anakku ini, atas dasar bahwa kamu bekerja denganku delapan tahun dan jika kamu cukupkan sepuluh tahun maka itu adalah (suatu kebaikan) dari kamu, maka aku tidak hendak memberati kamu. Dan kamu Insya Allah akan mendapatiku termasuk orangorang yang baik" (QS. al-Qaṣaṣ [28]: 27 - 28)

Berdasarkan kronologi turunnya ayat, maka ayat di atas termasuk dalam kategori makiyyahakhir ${ }^{27}$ dan merupakan ayat pertama dalam membahas tentang pernikahan yang includ didalamnya persoalan mahar. Ayat tersebut bekaitan dengan pernikahan Musa A.S dengan putri Syuaib a.s. Pernikahan akan dilakukan tersebut dengan syarat Musa harus menggembalakan ternak kambing Syuaib selama delapan tahun. Dan jika Ia menambah dua tahun lagi secara sukarela, maka itu adalah kebaikan untuk dirinya. Tetapi jika tidak, maka delapan tahun sudah cukup.

Musa a.s menerima syarat yang di ajukan oleh Syuaib, sehingga dia berkata kepada mertuanya (Syuaib):

"Urusan ini sesuai dengan apa yang telah engkau katakan bahwa engkau mempekerjakanku selama delapan tahun, jika aku menyelesaikan kontrakku selama sepuluh tahun maka tambahan (lebihan 2 tahun) itu dariku secara sukarela. Dan manakala aku menyelesaikan yang mana saja di antara kedua masa yang terpendek, berarti aku telah memenuhi janjiku dan bebas dari keterikatan." 28

Menurut al-Thabari dalam kitab tafsirnya, bahwa maksud dari ucapan Syuaib engkau bekerja kepadaku (an ta'jurani) adalah bentuk mahar yang harus dibayar Musa as atas pernikahannya dengan anak Syuaib as, mahar tersebut berupa mengembala kambing selama delapan tahun, atau sepeuluh tahun jika memang Musa berbaik hati dan tidak keberatan. ${ }^{29}$ Pada lanjutan ayat di atas yakni QS. Al-Qaṣaṣ [28]: 28 menunjukkan bahwa yang dimaksud oleh Nabi Musa a.s. dengan jawabannya itu tiada lain berniat akan menyempurnakan masa yang paling sempurna di antara kedua masa

${ }^{27}$ Taufik Adnan Amal, Rekonstruksi Sejarah Alquran, (Jakarta: Devisi Muslim Demokratis, 2011), hlm. 121. Lihat juga pengelompokan yang ditulis oleh Aksin Wijaya dalam Sejarah Kenabian, Dalam Perspektif Tafsir Nuzuli Muhammad Izzat Darwazah, (Bandung: Mizan, 2016), hlm. 50

${ }^{28} \mathrm{Abu}$ al-Fida' Ismail bin Umar bin Kasir, Tafsir Alquran al-'Azim Juz VI, (Bairut: Dar alThayyibah, 1999), hlm. 230.

${ }^{29}$ Abu Ja'far al-Tabari. Jāmi' al-Bayān fî̀ Ta’wīl al-Qurān Juz 19, ( Muassasah al-Risalah, 2000), hlm.565. 
tersebut (sepuluh tahun). Dengan artian Musa a.s ingin memberi hal yang terbaik dengan niat yang terbaik pula pada calon istrinya. ${ }^{30}$

Dua hal pokok yang dapat disarikan dari ayat di atas adalah kewajiban akan adanya wali dalam sebuah pernikahan (Syuaib) dan adanya mahar yang harus dibayar (mengembala kambing selama delapan tahun dan ditambah dua tahun). Kedua hal tersebut menjadi sesuatu yang harus terpenuhi dalam sebuah pernikahan. Berbeda dengan perilaku bangsa arab Jāhiliyah yang menganggap kedua hal tersebut sesuatu yang tidak penting. Surat tersebut menjadi konsep dasar pernikahan yang harus dilaksanakan oleh orang islam, (kewajiban adanya wali dan mahar secara sukarela) namun masyarakat arab pada waktu turunnya ayat tersebut belum cukup kuat untuk menerapkannya dalam kehidupan sehingga kelanjutan ayat-ayat pernikahan turun ketika nabi berada dimadinah.

Menurut Nashr Hamid, Ayat-ayat makiyyah merupakan inżar, yaitu berkaitan dengan pergulatan atau perubahan konsep-konsep lama dan seruan menuju konsep konsep baru dalam hal ini konsep pernikahan. Inżar bertujuan menggerakkan kesadaran masyarakat Arab telah terjadi kerusakan dan penyimpangan dalam realitas sehingga harus diadakan perubahan. ${ }^{31}$ QS.Al-Qasas [28]: 27 merupakan gambaran mahar yang sesuai dengan world view Alquran yaitu diberikan secara sukarela dan memilih yang paling banyak sebagai bentuk kasih sayang atas wanita yang dinikahinya. Pemaknaan mahar yang demikian belum terealisasi pada periode Makah bahwa pada periode ini Alquran tidak menyebutnya secara jelas dan kuat melainkan memuat konsep mahar dalam sebuah cerita Musa a.s sesuai dengan kebanyakan model teks-teks yang turun pada periode Makkah akhir ini.

\section{Periode Madinah}

Ayat tentang mahar turun pada fase madinah, hal tersebut karena pada fase madinah lah Alquran melakukan rekonstruksi sosial khususnya pada tradisi dan budaya bangsa Arab. Periode Madinah juga disebut dengan istlah fase risalah, yang memiliki fungsi membangun ideologi masyarakat baru, mengenalkan konsep-konsep baru yang sebelumnya belum banyak dibahas pada periode Makkah baik awal, tengah maupun akhir. Dalam ayat - ayat periode Madinah ini Alquran merespon tradisi mahar secara adoptif-rekonstruktif, yaitu mengambil dan membenahi adat mahar yang berlaku di masa Jāhiliyyah. Dan merekonstruksi praktek dan makna yang dikandung dalam tradisi mahar.

Diantara ayat Alquran yang membahas tentang mahar adalah QS. Al-Nisā' [4]: 4 yang berisi tentang tuntunan kepada wanita - wanita yang hendak dinikahi. ${ }^{32}$ Memang ketika itu hak- hak wanita baik yatim maupun tidak seringkali diabaikan. Karena itu

\footnotetext{
${ }^{30} \mathrm{Abu}$ al-Fida' Ismail bin Umar bin Kasir, Tafsir Alquran al-'Azim Juz VI, (Bairut: Dar alThayyibah, 1999), hlm. 231.

${ }^{31}$ Nashr Hamid Abu Zayd, Tekstualitas Alquran, Kritik Terhadap Ulum Alquran, trj. Khairon Nahdhiyyin, cet IV (Yogyakart: LkiS, 2005) hlm.90

${ }^{32}$ Lihat Tabel Susunan Kronologis Surat Periode Madinah dari penelitian Taufik Adnan Amal dalam bukunya Rekonstruksi Sejarah Alquran, (Jakarta: Devisi Muslim Demokratis, 2011), hlm. 122
} 
dalam ayat ini berpesan kepada semua orang khususnya para suami dan wali yang sering mengambil maskawin/mahar perempuan yang berada dalam perwalianya.

Adapun QS. Al-Nisā'[4]: 4 adalah sebagai berikut;

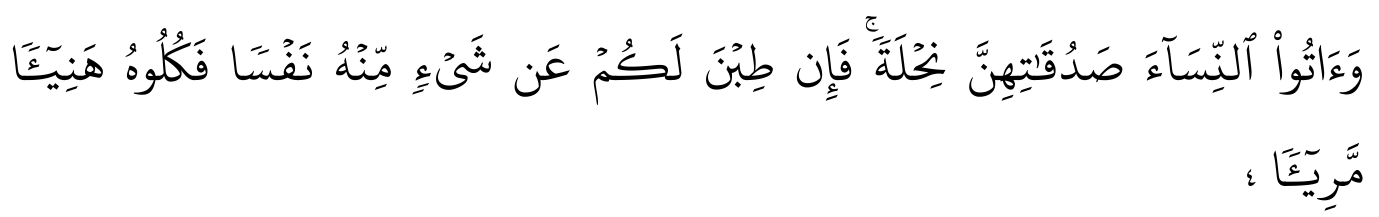

Terjemah: 4. Berikanlah maskawin (mahar) kepada wanita (yang kamu nikahi) sebagai pemberian dengan penuh kerelaan. Kemudian jika mereka menyerahkan kepada kamu sebagian dari maskawin itu dengan senang hati, maka makanlah (ambillah) pemberian itu (sebagai makanan) yang sedap lagi baik akibatnya.

Ali ibn Abu Talhah meriwayatkan dari Ibn Abbas, bahwa yang dimaksud dengan istilah nihlah dalam ayat ini adalah mahar. Muhammad ibn Ishaq meriwayatkan dari Al-Zuhri. dari Urwah, dari Siti Aisyah, bahwa nihlah adalah maskawin yang wajib.Ibn Zaid mengatakan, istilah nihlah dalam perkataan orang Arab artinya maskawin yang wajib." Disebutkan dalam sebuah hadis sebagai berikut;

"Janganlah kamu menikahinya kecuali dengan sesuatu (maskawin) yang wajib baginya. Tidak layak bagi seseorang sesudah Nabi Saw. menikahi seorang wanita kecuali dengan maskawin yang wajib. Tidak layak penyebutan maskawin didustakan tanpa alasan yang dibenarkan." ${ }_{33}$

Pada garis besarnya perkataan mereka menyatakan bahwa seorang lelaki diwajibkan membayar maskawin kepada calon istrinya sebagai suatu keharusan. Hendaknya hal tersebut dilakukannya dengan senang hati. Sebagaimana seseorang memberikan hadiahnya secara suka rela, maka seseorang diharuskan memberikan maskawin kepada istrinya secara senang hati pula. Jika pihak istri dengan suka hati sesudah penyebutan maskawinnya mengembalikan sebagian dari maskawin itu kepadanya, maka pihak suami boleh memakannya dengan senang hati dan halal.

Dalam tradisi pernikahan arab Jāhiliyyah ada yang memakai mahar dan tidak, namun bagi mereka yang memakai mahar memandang mahar sebatas alat pembayar dari laki - laki (sebagai pembeli) kepada orang tua wanita (sebagai pemilik atau penjual). ${ }^{34}$ Perkawinan dikategorikan sebagai transaksi jual beli antara calon suami dengan bapak calon mertua, sedangkan wanita dalam hal ini diperlakukan sebagai objek dari transaksi tersebut yang tidak memiliki hak apapun terhadap dirinya sendiri. ${ }^{35}$ Keadaan tersebut karena posisi wanita ditengah-tengah masyarakat yang inferior yakni berada dibawah bayang-bayang laki-laki bahkan tidak memiliki hak penuh sebagai warga. Keadaan tersebut memunculkan sistem sosial yang memandang

\footnotetext{
${ }^{33}$ Abu al-Fida' Ismail bin Umar bin Kasir, Tafsir Alquran al-’ Azim Juz II,.... hlm. 213

${ }^{34}$ Noel J Coulson, Hukum Islam dalam Perspektif Sejarah, trj. Hamid Ahmad, (Jakarta: P3M, 1987), hlm. 16-17.

${ }^{35}$ Ibid
} 
rendah status wanita. Pandangan lemah terhadap wanita berdampak panjang terhadap hukum yang berlaku di masyarakat, dan kebanyakan hukum yang berlaku mengalami bias gender termasuk dalam tradisi mahar.

Posisi wanita yang inferior menjadikan adanya bayak praktek pemberian mahar yang menyimpang. Diantaranya sebuah praktekdimana seorang laki laki datang menemui laki-laki lain dengan membawa saudara perempaunya dan memberikannya kepada laki-laki tersebut, kemudian laki-laki tersebut juga memberikan saudara perempuanya kepada laki-laki yang pertama, dan terjadilah pertukaran wanita sebagai mahar at as wanita yang lain. ${ }^{36}$

Selanjutnya, Alquran turun dengan membawa misi keadilan ${ }^{37}$ dan keagungan martabat manusia ${ }^{38}$ dalam persoalan mahar, sebagaimana dalam QS. Al-Nisā' [4]: 4 yang berpesan kepada semua orang khususnya para suami dan wali yang sering mengambil maskawin perempuan yang berada dalam perwalianya. Berikanlah maskawin / mahar kepada wanita yang kamu nikahi baik mereka yatim maupun bukan, sebagai pemberian dengan penuh kerelaan, lalu jika mereka wanita yang kamu nikahi dengan senang hati atau tanpa paksaan atau penipuan menyerahkan untuk kamu sebagian atau seluruh maskawin itu maka makanlah yakni gunakanlah pemberian itu sebagai pemberian yang sedap, lezat tanpa madharat lagi baik akibatnya.

Makna maskawin yang dibawa Alquran berbeda dengan makna maskawin pada masa Jāhiliyyah yang berarti sebagai alat jual beli, maskawin dalam ayat ini diartikan dengan șaduqāt yang merupakan bentuk jamak dari șadaqah yang terambil dari akar kata yang berarti kebenaran. Ini karena maskawin itu didahului oleh janji, maka pemberian itu merupakan bukti kebenaran janji. ${ }^{39}$ Dapat diartikan juga bahwa maskawin bukan hanya diartikan sebagai lambang yang membuktikan kebenaran dan ketulusan hati untuk menikah dan menanggung kebutuhan hidup istrinya, tetapi lebih dari itu, ia adalah lambang dari janji untuk tidak membuka rahasia kehidupan rumah tangga khususnya rahasia terdalam dalam rumah tangga yang tidak dibuka oleh seorang wanita kecuali kepada suaminya.

Pemaknaan maskawin diperkuat dengan kata nihlah yang berarti pemberian yang tulus tanpa sedikitpun mengharapkan imbalan, ia juga dapat berarti agama, sehingga maskawin yang diberikan tersebut tidak berasal dari paksaan dari pihak manapun melainkan karena dorongan tuntunan agama atau pandangan hidup. ${ }^{40}$

Dalam pembahasan mahar juga di atur perihal larangan untuk mengambil mahar / maskawin yang sudah dikeluarkan sebagaimana dalam QS.Al-Nisā'[4]: 20-21, meskipun mahar yang telah dikeluarkan tesebut berjumlah sangat banyak. Maksudnya bagaimana kalian tega mengambil kembali maskawin dari wanita. padahal kamu telah bergaul dan bercampur dengannya; dan ia pun telah bergaul dan bercampur denganmu.

\footnotetext{
${ }^{36}$ Abu Ja'far al-Tabari. Jāmi’ al-Bayān fì Ta’wìl al-Qurān Juz 7,..., hlm.553.

${ }^{37}$ QS. Al-Nahl [16]: 90

${ }^{38}$ QS. Al-Isrā' [17]: 70

${ }^{39}$ M. Quraish Shihab, Tafsir al-Misbah Volume 2, (Jakarta: Lentera Hati, 2002), hlm 346

${ }^{40}$ Ibid
} 
Menurut Ibn Abbas, Mujahid, Al-Saddi, dan ulama lainnya, yang dimaksud dengan 'bergaul' di sini ialah bersetubuh.

Larangan untuk menarik kembali mahar yang sudah diberikan menjadi sorotan Alquran, Alquran menolak kebiasaan jahiliyah yang menganggap mahar tidak lebih sebuah alat tukar sehingga ketika hubungan itu putus alat tukar juga dapat diambil kembali. Di dalam kitab Sahihain disebutkan bahwa Rasulullah Saw. Dengan bersabda kepada dua orang yang melakukan $l i$ 'an, sesudah keduanya selesai dari sumpah $1 i$ 'annya:

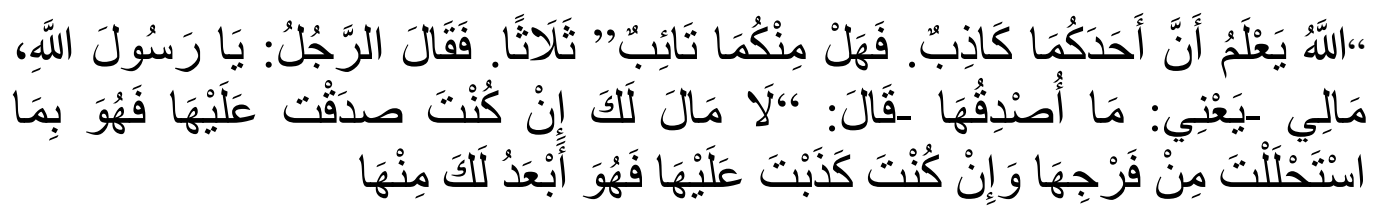

Allah mengetahui bahwa salah satu dari kalian berdua ada yang dusta, maka adakah di antara kamu yang man bertobat? Nabi Saw. mengucapkan kalimat ini sebanyak tiga kali. Maka si lelaki berkata, "Wahai Rasulullah. bagaimanakah dengan hartaku —yakni maskawin yang telah diberikan?" Nabi Saw bersabda: Kamu tidak mempunyai harta itu lagi, jika kamu telah memberikannya sebagai maskawin, maka hal itu sebagai imbalan dari apa yang telah engkau halalkan dari farjinya. Dan jika kamu adalah orang yang berdusta terhadapnya (istrimu), maka harta itu lebih jauh lagi bagimu dan lebih dekat kepadanya. ${ }^{41}$

Berdasarkan hadis di atas, maskawin yang sudah diberikan merupakan ganti atas farji yang sudah dihalalkan atas dirinya. Sehingga hendaklah direlakan karena itu menjadi imbalan kepadanya.

Larangan mengambil maskawin yang sudah diberikan juga atas dasar lantaran mereka (suami - istri) sudah mengikat janji yang kuat satu dengan yang lain dalam akad pernikahan, hubungan suami-istri dalam Alquran dibahasakan dengan mis̄àqan galizan / perjanjian yang kuat. Kata mis̄āqan galizan hanya ditemukan tiga kali dalam Alquran, pertama dalam ayat ini, yang melukiskan hubungan suami - istri, kedua menggambarkan perjanjian Allah dengan para rasul (QS.Al-Ahzab [33]: 7) dan ketiga dalam perjanjian Allah dengan manusia dalam konteks melaksanakan pesan - pesan agama (Al-Nisā‘ [4]: 154). Dengan demikian istilah mis̄āqan ġalizan berarti bahwa suami - istri sudah mengikat janji yang kuat dengan menyebut nama Allah dalam akad sehingga keduanya tidak bisa menganggap pernikahan hanya main - main yang dengan seenaknya sendiri dapat memutuskannya. Bahkan hubungan keduanya tidak hanya sekedar hubungan di dunia, namun juga sampai di akhirat kelak (QS. Yāsīn [36]: 56). ${ }^{42}$

Hal penting dalam pembahasan ayat ini adalah adanya penegasan atas kewajiban pemberian mahar dan merekonstruksi makna mahar menjadi sebuah pemberian sukarela sebagai bukti kasih sayang antar keduanya. Maka tidak heran ketika nabi

${ }^{41}$ Muhammad bin Isma'il Abu Abdillah al-Bukhari, Shahīh Al-Bukhari Juz VII, (Bairut: Dār Tuq al-Najāh, $1422 \mathrm{H})$, hlm.55

${ }^{42}$ Ibid, hlm 387. 
mekatakan bahwa sebaik-baik laki-laki adalah yang paling besar maharnya, sedangkan sebaik-baik wanita adalah yang paling kecil maharnya. Selain kewajiban pemberian mahar, dan rekonstruksi makna mahar juga dibahas tentang larangan untuk meminta kembali mahar yang sudah diberikan karena keagungan ikatan antara mereka, Allah menyebutnya mis̄àqan galizan.

\section{Interpretasi Proses Dialektika Alquran dengan Tradisi Mahar Bangsa Arab}

Jauh sebelum Alquran hadir, masyarakat jahiliyah sudah terselih dahulu mengenal masalah pernikahan, namun demikian kebiasaan tersebut jauh dari nilai dasar yang terkandung dalam Alquran yaitu nilai moralitas dan kemanusiaan. Termasuk didalamnya tradisi mahar yang berarti sebuah alat jual beli atas perempuan yang akan dinikahi.

Dialektika Alquran dengan tradisi mahar arab jahiliyyah sudah terjalin sejak awal Alquran itu diturunkan, lebih khususnya pada periode makkah akhir. Alquran menyinggung kisah pernikahan Musa dengan salah satu anak Syuaib yang didalamya terdapat ibrah dalam praktek mahar yang sesuai dengan Alquran. Namun demikian ayat tersebut hanya berfungsi sebagai inżar atau peringatan keras bahwa dalam praktek mahar masyarakat arab jahiliyyah banyak terjadi penyimpangan. Hal tersebut karena masyarakat arab jahiliyyah dipandang belum mampu untuk mempraktekkan model pernikahan yang sesuai dengan nilai-nilai dibawa Alquran.

Memasuki periode madinah, yang dikenal dengan sebutan dengan fase risalah, ${ }^{43}$ sorotan Alquran terhadap praktek mahar adalahperintah untuk memberikan mahar secara sukarela, dalam ayat ini juga ditegaskan peruntukan mahar adalah untuk mempelai wanita bukan wali nikah. Ayat tentang mahar, dilanjutkan larangan meminta kembali mahar yang sudah diberikan ketika terjadi perceraian.

\section{Fase Tasyakkul Dan Tasykī ${ }^{4}$ Dalam Tradisi Mahar}

Adanya dialektika antara wahyu Alquran dengan tradisi mahar masyarakat arab jahiliyyah itu berarti al-Qur'an telah memasuki wilayah kesejarahan manusia, dan ketika ia memasuki wilayah kesejarahan manusia, maka merupakan keniscayaan bagi al-Qur'an untuk memakai struktur tata-bahasa dan tata-budaya Arab untuk menyampaikan misi Risalah-Nya melalui Muhammad. Fase ketika teks al-Qur'an membentuk dan mengkonstruksikan diri secara struktural dalam sistem budaya yang

\footnotetext{
${ }^{43}$ fase risalahmemiliki fungsi membangun ideologi masyarakat baru, mengenalkan konsep-konsep baru yang sebelumnya belum banyak dibahas pada periode Makkah baik awal, tengah maupun akhir. Lihat dalam Nashr Hamid Abu Zayd, Tekstualitas Alquran, Kritik Terhadap Ulum Alquran,... hlm.90

${ }^{44}$ Konsep Tasyakkul dan Tasykil dikenalkan oleh Nasr Hamid Abu Zaid dalam bukunya Mafhūm Al-Nas yang dengan konsepnya ini Nashr Hamid ingin mengatakan bahwa ketika di wahyukan kepada Muhammad yang hidup di Jazirah Arab dengan segala budaya dan tradisinya, itu berarti al-Qur'an memasuki wilayah kesejarahan manusia, dan ketika ia memasuki wilayah kesejarahan manusia, maka merupakan keniscayaan bagi al-Qur'an untuk memakai struktur tata-bahasa dan tata-budaya Arab untuk menyampaikan misi Risalah-Nya melalui Muhammad. Lihat Nashr Hamid Abu Zaid, Mafhum Nash; Dirosah fi Ulum Al-Qur'an, Terj. LKiS "Tekstualitas Al-Qir'an; Kritik Terhadap Ulumul Qur'an",... hlm. 24
} 
melatarinya (budaya mahar), dimana aspek kebahasaan merupakan salah satu bagiannya. Fase inilah yang kemudian disebut periode pembentukan (marhalah altasyakkul).

Kemudian, Fase ketika teks al-Qur'an membentuk dan mengkonstruksi ulang sistem kebudayaannya (budaya mahar), yaitu dengan menciptakan sistem kebahasaan khusus yang berbeda dengan bahasa induknya dan kemudian memunculkan pengaruh dalam sistem kebudayaannya. Mahar yang semula bermakna alat tukar terhadap kemaluan wanita, berubah menjadi pemberian wajib secara sukarela. Dalam fase disebut sebagai periode pembentukan (marhalah tasykil). Teks yang semula merupakan produk kebudayaan, kini berubah menjadi produsen kebudayaan.

\section{Telaah Antropologis: Agama Sebagai Budaya}

Dari perspektif antropologi, pembentukan hukum mahar dalam Alquran mengalami proses dialektika, yang terjadi antara wahyu Alquran dengan tradisi mahar setempat (bangsa arab jahiliyyah). Dialektika ini terjadi secara bertahab melalui proses adopsidan rekonstruksi. Pada awalnya Alquran mengadopsi tradisi mahar setempat dan mengakuinya sebagai sebuah tradisi yang hidup (model of reality). Berikutnya Alquran menginovasi tradisi tersebut dan melakukan penyesuaian dalam keberlakuannya. Dalam proses rekonstruksi, Alquran menkonstruksi tradisi mahar sesuai dengan world view Alquran yaitu keadilan dan keagungan martabat manusia. Melalui proses ini Alquran berdialog dengan tradisi mahar dan menghasilkan sebuah sistem simbol. Dan sistem simbol tersebut membentuk pola-pola budaya yang pada gilirannya membentuk sebuah model (model for reality), yaitu memberikan konsep atau doktrin untuk realita.

Dalam hal ini Geertz tidak menganjurkan untuk mengabaikan pentingnya pandangan-pandangan para antropolog terdahulu, akan tetapi lebih menganjurkan perlunya memperluas perspektif dan mengakui bahwa agama pada dasarnya merupakan suatu sistem kultural yang memberikan makna dalam eksistensi manusia. Agama memiliki fungsi universal dalam memberikan makna tersebut. Geerts menulis;

Agama adalah suatu sistem simbol yang berfungsi untuk mengukuhkan suasana hati dan motivasi yang kuat, mendalam dan tak kunjung padam dalam diri manusia dengan memformulasikan konsepsi tentang tatanan umum eksistensi dan membungkus konsepsi itu dengan aura aktualitas yang bagi perasaan dan motivasi nampak realitas. ${ }^{45}$

Oleh karena itu, Geertz mengemukakan bahwa simbol-simbol keagamaan memformulasikan adanya suatu persesuaian mendasar antara tipe kehidupan partikular dengan metafisika tertentu yang berfungsi untuk mensintesakan etos masyarakat model estetika, kebiasaan, dan kualitas kehidupan mereka- dengan padangan dunianya, yaitu ide-ide mengenai keteraturan yang paling komprehenshif. Struktur simbolik

\footnotetext{
${ }^{45}$ Brian Morris, Antropologi Agama Kritik Teori-Teori Agama Kontemporer, Trj. Imam Khoiri, (Yogyakarta: AK Group, 2007), hlm. 393.
} 
secara intrinsik memiliki aspek ganda, menjadi suatu model dari "realitas" (model of reality) dan model bagi "realitas" (model for reality), kedua aspek tersebut mengekspresikan suasana dunia dan membentuknya.

Menurut geertz setidaknya terdapat empat fungsi dasar keyakinan keagamaan, pertama berfungsi memberikan makna. Kedua, berfungsi untuk menawarkan suatu penjelasan atas peristiwa-peristiwa dan pengalaman yang menyimpang dari kebiasaan. Ketiga, memberikan pemahaman dan dukungan emosional terhadap penderitaan yang dialami manusia. Keempat, memberikan kriteria etis yang dapat dijalankan untuk menjelaskan diskontinuitas antara sesuatu sebagaimana adanya (as they are) dan yang semestinya (as they ought to be). ${ }^{46}$

\section{Penutup}

Pemaknaan atas mahar tidak berhenti pada sebuah arti pemberian suami pada istri, sebagaimana pemaknaan normatif atas mahar, lebih-lebih pemaknaan bangsa jahiliyyah yang menganggapnya sebagai bentuk alat tukar terhadap wanita yang akan dinikahi. Melainkan mahar diartikan sebagai pemberian wajib atas bukti cinta dan kesungguhan (saduqāt) yang diberikan secara sukarela (niḥlah) dengan niat beribadah kepada Allah. Pemaknaan tersebut sesuai dengan pesan yang dibawa Alquran (world view Alquran) yaitu keadilan dan keagungan martabat manusia.

\section{DAFTAR PUSTAKA}

Abidin, Slamet. Fiqih Munakahat 1. Bandung: CV Pustaka Setia.1999.

Abu Zayd, Nashr Hamid. Tekstualitas Alquran. Kritik Terhadap Ulum Alquran. trj. Khairon Nahdhiyyin. cet IV Yogyakart: LkiS. 2005.

al-Bukhari, Muhammad bin Isma'il Abu Abdillah. Shahīh Al-Bukhari Juz VII. Bairut: Dār Tuq al-Najāh. 1422 H.

al-Tabari, Abu Ja'far. Jāmi' al-Bayān fî Ta’wīl al-Qurān Juz 19. Muassasah al-Risalah. 2000.

al-Tabari, Abu Ja'far. Jāmi' al-Bayān fĩ Ta’wīl al-Qurān Juz 7. Muassasah al-Risalah. 2000.

Amal, Taufik Adnan. Rekonstruksi Sejarah Alquran. Jakarta: Devisi Muslim Demokratis. 2011.

Barakat, Halim. Dunia Arab. Masyarakat. Budaya dan Negara. Bandung: Nusa Media. 2012.

Coulson, Noel J. Hukum Islam dalam Perspektif Sejarah. trj. Hamid Ahmad. Jakarta: P3M. 1987.

Darmawan. Eksistensi Mahar \& Walimah. t.t: Srikandi, 2007.

\footnotetext{
${ }^{46}$ Ibid. 394
} 
Engineer, Asghar Ali. Asal Usul Perkembangan Islam.

Hanafi, Hassan. 'Ulūm al-Sirah: Min al-Rasūl ila al-Risālah. Kairo: Madbuli. 2013.

Hisyam, Ibnu. Sïrah Nabawiyyah. Juz I Kairo: Dār al-Fikr. t.th .

Hitti, Philip K. History Of The Arabs. Jakarta: Serambi Ilmu Semesta. 2008.

Kasir, Abu al-Fida' Ismail bin Umar. Tafsir Alquran al-'Azim Juz VI. Bairut: Dar alThayyibah. 1999.

Kasir, Abu al-Fida' Ismail bin Umar. Tafsir Alquran al-'Azim Juz II. Bairut: Dar alThayyibah. 1999.

Khaldun, Ibnu. Muqadimah Ibnu Khaldun. terj. Ahmadie Thaha. Jakarta: Pustaka Firdaus. 2006.

Lapidus, Ira M. Sejarah Sosial Ummat Islam. Bagian Kesatu dan Kedua. trj. Gufron A. Mas'adi. Jakarta: Rajawali Press. 1999

Morris, Brian. Antropologi Agama Kritik Teori-Teori Agama Kontemporer, Trj. Imam Khoiri. Yogyakarta: AK Group. 2007.

Shihab, M. Quraish. Tafsir al-Misbah Volume 2. Jakarta: Lentera Hati. 2002.

Shihab, Quraish. Membaca Sirah Nabi Muhammad Dalam Sorotan Alquran Dan HaditsHadits Shahih. Jakarta: Lentera Hati..

Sodiqin, Ali. Antropologi Alquran: Model Dialektika Wahyu dan Budaya. Yogyakarta: Arruz Media. 2008.

Soetapa, Djaka. Ummah: Komunitas Religius. Sosial dan Politis dalam Alquran. Yogyakarta: Duta Wacana University Press. 1991.

Wadud, Amina. Quran And Women. Reading The Sacred Text From A Woman's Perspektive. Oxford: Oxford Unniversity Press. 1999.

Wijaya, Aksin. Sejarah Kenabian. Dalam Perspektif Tafsir Nuzuli Muhammad Izzat Darwazah. Bandung: Mizan. 2016.

Zulkifli. Mozaik Sejarah Islam. Yogyakarta: Nusantara Press. 